Social Work/Maatskaplike Werk Vol 56 No 1; Issue 5

http://socialwork.journals.ac.za/pub

doi:http://dx.doi.org/10.15270/56-1-790

REVISITING GENDER AND HOUSING: HOUSING AS SEEN THROUGH THE EYES OF WOMEN IN SOCIAL RENTAL HOUSING IN GAUTENG, SOUTH AFRICA

Mziwandile Sobantu

This paper reports part of the findings of a bigger qualitative study which explored the role of social rental housing in housing delivery in South Africa. Through purposive sampling, the study selected three housing institutions from Gauteng and two from the Western Cape. From each, the study conducted a focus group discussion with beneficiaries. This paper is based on the findings from the two focus group discussions with women in Gauteng. Findings showed that housing is central to the wellbeing of women. The paper recommends gender-aware housing delivery processes to promote the rights of women and children.

Dr Mziwandile Sobantu, Lecturer, Department of Social Work, University of Johannesburg, Johannesburg, South Africa.

Email address, msobantu@uj.ac.za/sobantu.mzwandile@gmail.com

KEY WORDS: gender, women, housing, housing delivery, social rental housing, South Africa. 


\title{
REVISITING GENDER AND HOUSING: HOUSING AS SEEN THROUGH THE EYES OF WOMEN IN SOCIAL RENTAL HOUSING IN GAUTENG, SOUTH AFRICA
}

\section{Mziwandile Sobantu}

Mziwandile Sobantu, ORCiD Id: 0000-0002-8516-4623

\author{
Dr Mziwandile Sobantu, Lecturer, Department of Social Work, University of Johannesburg, \\ Johannesburg, South Africa.
}

KEY WORDS: gender, women, housing, housing delivery, social rental housing, South Africa.

\section{INTRODUCTION}

Across time and place housing has played a central role in building families and communities as well as shaping the social and economic fabric of society. Hohmann (2013) posits that because of their role in the social and economic development of societies, professions such as social work, law and engineering are increasingly attracting interest in housing discourse and practice. In South Africa the African National Congress-led government has made huge strides in providing mass housing since 1994. However, many criticisms have been directed against the way in which it has been implementing the individual housing subsidy programme, popularly known as the RDP, which was later replaced by the Breaking New Ground (BNG) in 2004 (Noyoo \& Sobantu, 2019; Sobantu, Zulu \& Maphosa, 2019). Since the BNG was implemented, not much perceptible progress has not been realised in terms of improved housing access for women and other vulnerable populations (Pithouse, 2009; Noyoo \& Sobantu, 2019; Sobantu, 2019; Sobantu et al., 2019). Among other criticisms, Fish (2003:405) points out that the RDP housing programme was "not appropriately geared to address the needs of femaleheaded households... [and] ignores the demographic data that 20-45 per cent of households in informal settlements are women." Gender blindness in providing social welfare services such as housing assumes that men and women have equal opportunities to access housing and that they also experience housing or lack of it in a similar way. This paper examines the meaning and the importance of housing from the empirical perspectives of women who are beneficiaries of social rental housing in South Africa.

The interests of poor women in South Africa cannot be disentangled from the housing challenges that they face. Housing is central to women, as the "domestic production of life and livelihood" is key to them (Waetjen \& Vahed, 2012:262). Jones (2014) and Jones and Teixeira (2015) observe that the wellbeing, safety, security and stability of children and families are the ultimate concern for women. Waetjen and Vahed (2012:262) add that women's influence transcends family boundaries because community challenges are "directly connected to the domestic sphere, such as housing and service delivery." Thus, a nation that is concerned about its children's education, and the safety and security of its vulnerable population cannot afford to be gender-blind in housing delivery. Unequal power relations between men and women in relation to housing need to be understood in order to promote equality through gender-aware housing delivery processes (Saugeres, 2009; Sobantu, 2014; Sobantu et al., 2019; Waetjen \& Vahed, 2012).

The participation of women in shaping housing delivery policies and even in home-making is being undermined by certain forms of exclusion and discrimination, as articulated in the excerpt below by Dietrich (1987:1793), who pointed out the fact that

... women and men are affected by housing problems in very different ways becomes apparent if one considers that housing involves access to a basic minimum area of land, legal and social security of tenure ... which often blatantly violates women's constitutional right to 
equality. Women's housing rights (or lack of them) are entirely mediated by the compulsion to get married within patriarchal rules of the game.

In addition, Dietrich 1987:1793 notes that, despite their pivotal role in shaping the housing and human settlements environment, women's influence in making decisions around home-making processes is "in fact diminishing." Waetjen and Vahed (2012) emphasise that there is a strong intersection between gender-based violence, poverty and lack of housing for women. Sobantu (2019) also highlights the need for a gender-aware housing delivery process in order to improve housing access for women and enhance their safety in the built environment. Therefore, Gandhi (1987:1994) implores "planners and policy-makers to re-examine their basic assumptions, especially those regarding women." Statistics South Africa (2018) indicates an increase in the number of women who have benefited from RDP housing. However, the need for gender-aware housing delivery processes is more relevant today, given the feminisation of poverty (Noyoo \& Sobantu, 2019; Todes, Malaza \& Williamson, 2009; Raniga, 2018; Raniga \& Ngcobo, 2014; Waetjen \& Vahed, 2012) as well as the scourge of domestic and gender-based violence and abuse against children (Abrahams, Jewkes \& Mathews, 2010; Jewkes, Dunkle, Nduna \& Shai, 2010; Statistics South Africa, 2018; Woollet \& Thompson, 2016). The author contends that integrating women's voices and their understanding of housing into housing policy will redirect housing delivery processes towards more gender-responsive pathways. According to Director and Clark (2011), it is a social work mandate to engage in advocacy as part of policy practice to promote social justice and the human rights of vulnerable populations, which includes women and children.

\section{HOUSING AND GENDER}

In view of its implications for women and communities, housing planning needs to occupy a central position in social policy (Arku, 2006; Carter \& Polevychok, 2004). For significant progress to be made in achieving social policy goals of promoting gender equality, eradicating poverty, growing the economy, promoting social inclusion and addressing the scourge of gender-based and domestic violence, women's access to safe and secure housing and human settlements need to be prioritised (Carter \& Polevychok, 2004; Dietrich, 1987; Gandhi, 1987; Jewkes et al., 2010; Lanus, 2009; Paglione, 2006). Since men and women experience the urban space in terms of transport, sanitation and housing differently, a gender-sensitive approach is imperative to build inclusive cities that cater for women's needs (Dietrich, 1987; Gandhi, 1987; Todes et al., 2009; Waetjen \& Vahed, 2012). In their advocacy for gender-inclusive settlements, Todes et al. (2009:1) argue that "urban labour markets often remain segmented along gender lines; many poor women find jobs as housemaids, cleaners or vendors. Can they get housing, or access public transport to reach their jobs?"

Gender-inclusive settlements would ensure that women have access to affordable housing and enjoy the related socio-economic rights such as electricity, sanitation and water. Housing access enhances women's stability, self-esteem and dignity as well as empowering them to navigate through other challenges in their lives (Malpass, 2001; Olufemi \& Reeves, 2004:69; Saugeres, 2009; Waetjen \& Vahed, 2012). Therefore, for social workers, planners and politicians to be more effective in promoting and protecting the rights of women, older persons, people with disabilities and children, they need to understand the struggles of women, the challenges they contend with in the urban space and their potential, if supported, to contribute positively to human settlements. This is because housing undergirds all social and economic relations (Hohmann, 2013) and any endeavour to curb crime and violence needs to start and end in housing and integrating the voices of women in planning (Sobantu, 2019; Sobantu et al., 2019). Because of their role in raising children and families, women's "real need is the right to secure tenure and the right to stay in a place without being harassed" (Dietrich, 1987:1793). Women's conceptualisation and understanding of housing is deeply cognisant of their children's need for a "safe and healthy environment that is conducive to learning" (Cunningham \& MacDonald, 2012 in Pillay, 2017:1). Thus, housing delivery that is reconfigured to suit the needs of 
women goes a long way in improving human capital in respect of children and creating a safe, secure and stable environment.

As architects of family space and relations, it is important that women have access to quality housing in secure human settlements and neighbourhoods for them to engage productively in homemaking activities. Depres (1991) and Kellet and Moore (2003) define homemaking as those activities that involve converting the physical components of 'brick and mortar' into a home that offers peace, stability, love, warmth, understanding, self-esteem and dignity for the occupants. A home then reflects family expressions and represents permanence and stability. Because of the stability it fosters, a home becomes a centre of activities which draws families and friends from the neighbourhood and beyond (Depres, 1991; Kellet \& Moore, 2003). Waetjen and Vahed (2012:262) highlight that women create housing environments that are "more caring ... assuming responsibility of running the home." Previous studies such as those by Csikszentmihalyi and Halton (1981), Kellet and Moore (2003), Paglione (2006), Rakoff (1977), Sebba and Churchman (1986) and Sobantu (2019) emphasise how women ensure that their housing arrangements reflect peace, understanding, patience, family, order, love, growth and human dignity. Several questions arise, then, about a country such as South Africa where violence against women, young and old, as well as their children, is rife. One of these questions is: "Whose voices prevail when our houses and settlements are built, in an environment with so much violence against its people?" Because women are largely "responsible for the welfare of the family and ... [are] the primary users of the home in performing domestic chores" (Gandhi, 1987:1994), it is essential that their voices be heard when determining housing processes.

This paper adds to the sparse literature on the understanding of housing from the perspectives of South Africa's low-income women and how their housing circumstances can be improved. This is important in the light of the feminisation of poverty, which leads to low housing affordability for women because of their meagre incomes (Raniga, 2018; Raniga \& Ngcobo, 2014; Jones, 2014:7). Almost 25 years into a democratic dispensation, women are still poorer than men in South Africa, with less access to housing and other services and amenities (Statistics South Africa, 2018). Moreover, they are victims of different forms of abuse, which could be addressed through bottom-up, gender-aware housing delivery (Noyoo \& Sobantu, 2019; Paglione, 2006; Sobantu et al., 2019; Todes et al., 2008).

\section{SOCIAL RENTAL HOUSING IN SOUTH AFRICA}

Social rental housing is one of the delivery pathways that the South African government uses to provide accommodation for low- to middle-income earners. Through the 2008 Social Housing Act, interested Social Housing Institutions (SHIs) can partner with government after registering with the Social Housing Rental Authority (SHRA) (Republic of South Africa, 2008). Through SHRA, the government disburses institutional subsidy funding to the SHIs so that they can build rental housing for qualifying applicants. SHRA defines social rental housing as "a rental or co-operative housing option which requires institutionalised management which is provided by accredited social housing institutions or in accredited social housing projects in designated restructuring zones." Unlike RDP housing which is owned by the beneficiaries, social rental housing does not offer an ownership option (Republic of South Africa, 2008).

To qualify for social rental housing, applicants need to have a monthly household income of between R5 000 to R15 000 (SHRA, 2018). While it is not delivered on scale like RDP housing, the main purpose of social housing, according to the 2005 Social Housing Policy (Republic of South Africa, 2005) and the 2008 Social Housing Act, is to reconfigure apartheid spatiality by drawing low- and middle-income earners towards the city - closer to services. While this has been criticised for excluding the poorest from benefiting (Charlton, 2013), it has nonetheless been lauded for its proximity to services and for the particular consideration it gives to women, especially single parents (Fish, 2003; Noyoo \& Sobantu, 2019). In order for social rental housing to remain viable, Noyoo and Sobantu (2019) urge SHIs to take steps to safeguard their own financial independence and to integrate beneficiary voices. At the same time, government needs to support these institutions and empower 
women economically to enhance their ability to afford housing to qualify for social rental housing and other options.

\section{THEORETICAL LENS}

A gender lens is deemed key to understanding the housing experiences of women. While a focus on women and gender in human rights and development discourse has gained pace, "strangely, very little academic work in housing studies ... has used feminist and gendered perspectives to understand social inequalities in relation to housing" (Saugeres, 2009:194). Gender is an evolving and complex concept (Tilley, Bieri \& Kohler, 2013:302; Bourdieu, 1990); it does not simply refer to men and women (Saugeres, 2009:194-195) but it is

"socially constructed and that this social construction is unequal because it produces patriarchal structures of power by which men dominate and control women ... It is a product of history which produces individual and collective practices that come to reaffirm and validate their existence ... what is socially constructed as male and masculine is seen as superior, and what is constructed as female and feminine is considered to be inferior."

In relation to housing and to the focus of this chapter specifically, a gender lens is then key to understanding the ways in which women need to be prioritised in housing delivery, because much of housing theory, research and policy does not acknowledge the different ways in which gender ideologies and gender relations within the family and the labour market shape women's and men's housing experiences and needs differently (Boje \& Lena, 2000 in Saugeres, 2009:194).

In a similar vein, Dietrich (1987:1793), Todes et al. (2009:1) and Waetjen and Vahed (2012:262) argue that gender blindness in housing delivery and urban development is insensitive to the struggles of women who are affected by the feminisation of poverty and discrimination by various institutions in the society. Therefore, this paper uses a gender lens as an analytical tool to promote transformation towards a more gender-sensitive approach to housing delivery and urban planning. Through examining women's experiences of housing, this study draws attention to the numerous benefits that are likely to accrue to families when housing delivery is driven by a gender-aware approach.

A gender lens in housing is in line with social justice and anti-oppressive practices. This is because women are "the primary users of the home in performing [both] domestic and paid labour" (Gandhi, 1987:1997) and they are responsible for "the domestic production of life and livelihood" (Waetjen \& Vahed, 2009:262). Having said this, a paradox is that their access to housing and "decision-making over housing is ... diminishing" (Dietrich, 1987:1793). A gender lens is also redistributive and rightsbased in its stance insofar as women should have the right to affordable housing, self-determination and a violence-free urban space. Housing delivery "cannot remain a [gender-]neutral exercise - but a process that should be predicated on social justice and human rights as articulated in the Bill of Rights" (Sobantu et al., 2019:2).

\section{RESEARCH METHODOLOGY}

The study adopted a qualitative approach and an exploratory design. The study drew participants through volunteer sampling from three SHIs in Gauteng and two from the Western Cape. This paper presents a segment of information from a larger data set gathered from three SHIs in Gauteng and the two from the Western Cape. The focus of this paper is the analysis of participants' understanding and experience of social rental housing from a gender perspective. As the focus groups in Gauteng (one in Tshwane and the other in Johannesburg) were comprised exclusively of female participants, the data from these two focus groups are presented in this paper. The data set gathered from the Western Cape will be the focus of subsequent papers. 
The housing institutions were purposively selected based on their registration with SHRA as SHIs. Through the help of the SHI managers as gatekeepers, the researcher invited beneficiaries in each SHI to volunteer to participate in a focus group discussion. According to Morse (1991:131), volunteer sampling is useful when it is difficult for the researcher to reach the potential participants. In collaboration with the gatekeepers, the researcher posted adverts in the SHIs. The criteria for participation were that 1) both males and females could participate in the study; 2) participants needed to be beneficiaries of social rental housing for a minimum of two years; 3 ) participants needed to have a housing unit their SHIs; and 4) they would be willing to participate in a focus group discussion. The interested individuals gave their contact details to the gatekeepers for the researcher to communicate with them regarding arrangements for the focus group discussions.

Of the five SHIs, only two were comprised of only female participants. This paper is based on the discussions with these two women-only focus groups from Gauteng, because their responses resonate with the gender perspective to housing delivery. See Table 1 for the biographical details of these participants. Only the data from these two focus groups were considered for this paper, because it reflected the women's views in line with the gender lens on housing delivery. A focus on these two focus group discussions still resonates within the scope of the larger study. The bigger study advocated for responsive housing delivery processes in order to address the needs of vulnerable populations, which includes women and children (Sobantu, 2019).

\section{TABLE 1}

PROFILE OF PARTICIPANTS

\begin{tabular}{|c|c|c|c|c|c|c|c|c|c|}
\hline 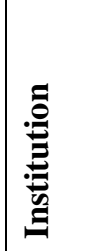 & 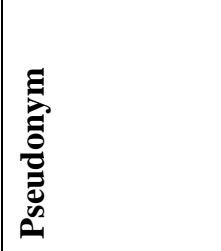 & 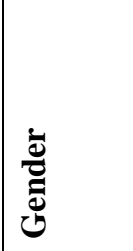 & שֶّ & $\underset{4}{80}$ & 递 & 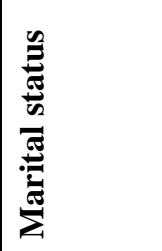 & 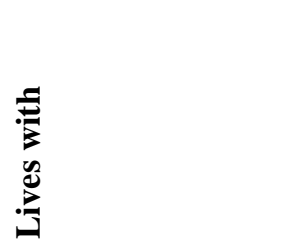 & 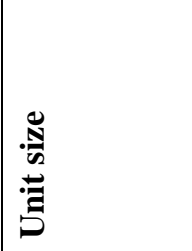 & 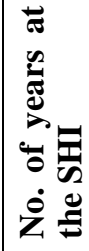 \\
\hline \multirow{7}{*}{ 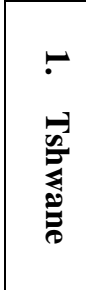 } & Participant 1 & Female & Black & 32 & Clerk & Single & Son & Room & 4 \\
\hline & Participant 2 & Female & Black & 21 & Student & Single & Alone & Room & 3 \\
\hline & Participant 3 & Female & Black & 36 & Self-employed & Single & Partner & Bachelor & 3 \\
\hline & Participant 4 & Female & Black & 42 & Secretary & Married & Husband, 1 child & Bachelor & 7 \\
\hline & Participant 5 & Female & Black & 33 & Metro police & Single & Partner, 1 child & 1 Bedroom & 3 \\
\hline & Participant 6 & Female & Black & 36 & Hairdresser & Married & Husband, 2 children & 1 Bedroom & 4 \\
\hline & Participant 7 & Female & Black & 40 & Bank call centre & Separated & Alone & Room & 5 \\
\hline \multirow{2}{*}{ 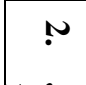 } & Participant 8 & Female & Black & 34 & Housewife & Married & Husband, 2 children & 2 Bedrooms & 6 \\
\hline & Participant 9 & Female & Black & 22 & Student & Single & Alone & Room & 4 \\
\hline \multirow{5}{*}{ 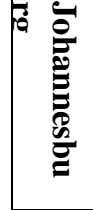 } & Participant 10 & Female & Black & 35 & Self-employed & Single & Partner & Room & 7 \\
\hline & Participant 11 & Female & Black & 20 & Student & Single & Sister & Bachelor & 3 \\
\hline & Participant 12 & Female & Black & 20 & Student & Single & Sister & Bachelor & 3 \\
\hline & Participant 13 & Female & Black & 28 & Waiter & Married & Wife, 2 children & 1 Bedroom & 4 \\
\hline & Participant 14 & Female & Black & 37 & Self-employed & Divorced & Alone & Room & 6 \\
\hline
\end{tabular}

Ethics approval was obtained from the University of Johannesburg's Ethics Committee to conduct this study and each SHI gave the researcher an approval letter to undertake the study in their institutions. All the participants gave consent to participate in the focus group discussions and to have the conversations recorded. Gill, Stewart, Treasure and Chadwick (2008:293) define a focus group as a "discussion on a particular topic organised for research purposes." Greef (2013:360) adds that focus groups allow individuals to "present their own views and experience ... also [to] hear from other people." The focus groups lasted 60-90 minutes and a facilitator was used to guide the discussion, centring on the participants' understanding and experiences of housing.

Thematic analysis was used to interpret the data collected from the two focus groups. In line with Braun and Clarke (2006), the researcher reviewed the transcripts and field notes, and listened to the 
recordings to familiarise himself with the data and check for any data that might have been omitted (Anney, 2014; Shenton, 2004). Through this reflexive process (which also ensured rigour, accuracy and dependability of data), the researcher was able to identify common themes. These were finalised by matching them with participants' responses (Braun \& Clarke, 2006).

\section{THE PROFILE AND DEMOGRAPHIC DETAILS OF THE PARTICIPANTS}

The 14 participants in the two Gauteng focus groups were all female and black. This confirms the literature which points to the racialisation as well as feminisation of poverty (Özler, 2007; Raniga \& Ngcobo, 2014:516; Waetjen \& Vahed, 2009). Five of the participants were living alone, while two (students and twins) lived together. Two others lived with their partners and had no children, while five were either married or lived with partners and with their children. Altogether, four of the single participants were students. Their ages ranged from 20 and 42 and the average age was 31 years. As per the selection criteria, all participants had been in their housing institutions for three years or longer, with Participant 4 being in her seventh year. In terms of their livelihood activities, five were formally employed, four were self-employed, four were full-time students and one was a housewife. The three who were self-employed were also single. The study found that those who were in full-time employment received low incomes that did not enable them to acquire housing loans from the bank. Moreover, they indicated that they had other financial responsibilities in their families.

Considering that SHIs provide low-income subsidised rental accommodation and that all the participants were black women and most were single emphasises the need for a gender-aware housing delivery process (Fish, 2003; Jones \& Teixeira, 2015; Khan, 2003, Larson, 2001; Todes et al., 2009; Mulroy, 1988; Nishimwe-Niyimbanira, 2013; Raniga \& Ngcobo, 2014). Furthermore, Noyoo and Sobantu (2019:37) stress that the government needs to take urgent steps to provide "decent and affordable housing to ... its poor and vulnerable citizens", especially for women who are single parents. This is because the poverty statistics in terms of gender (Frye, 2007 in Raniga and Ngcobo, 2014:516; Statistics South Africa, 2018) indicate persistently that "women who are single parents from impoverished communities face social and economic exclusion in both the first economy and second economy." Women's ability to afford housing diminishes as a consequence of their economic exclusion. Therefore, women's housing rights continue to be undermined.

\section{INTEGRATED DISCUSSION OF FINDINGS}

The key themes arising from the focus group discussions with the participants were related to the gender theoretical lens, highlighting that women's access to affordable and quality housing needs to be promoted. This is because of the multiplier effect that women's access has on families, communities and the economy.

In the discussion of the findings, participants are identified only by their numbers, as shown in Table 1 . The use of verbatim quotes from the interviews ensures that the participants" "voices and stories [and understanding] remain a central focus" (Sobantu \& Warria, 2013:576). The discussion of findings focuses on three themes: i) safety and security, ii) privacy and dignity, and iii) convenient location of services and amenities.

\section{Safety and security}

According to Marslow's hierarchy of needs, human beings need privacy, safety and security in order to realise their full potential (Freitas \& Leonard, 2011; Zavei \& Jusan, 2012). The findings reveal that housing is an essential physical asset and a basic human need that provides shelter to protect the occupants from the elements (Anderson, 2010; Hohmann, 2013; Noyoo \& Sobantu, 2019; Sobantu, 2014, Sobantu et al., 2019). The participants indicated that their understanding of housing was informed by the functions that they expected housing to provide them with. For example, Participant 1 expressed the view that "as a woman and a single parent, housing means that I'm safe with my child, I have shelter." Similarly, Participant 5 observed that "I have a daughter and I need a good house in a safe place where she won't be afraid and that is why I've been here for seven years." Worth noting in 
the above excerpts is the participants' define housing in relation to themselves and their children. This can be understood in the light of the rampant incidents of violent crime against women and children in South Africa (Abrahams, Jewkes, Laubscher \& Hoffman, 2006; Abrahams et al., 2010; Gqola, 2007; Jewkes et al., 2010; Paglione, 2006; Woollet \& Thompson, 2016). In the majority, if not all, of the cases the women, as mothers, are very concerned about the wellbeing of their children (Saugeres, 2009; Waetjen \& Vahed, 2012); this was evinced by the participants who stated that housing ensured their children's safety, security and wellbeing. Issues of the security and even the physical safety of children in human settlements are a huge concern in South Africa; for example, perimeter walls have been known to collapse leading to the death of children. A child died in Doornfontein on 9 April 2018 (Shange, 2018) and two in Durban on 21 May 2018 because of a similar accident (Wicks, 2018). In Limpopo another child drowned in an open manhole on 14 January 2019 (Matlala, 2019). Such occurrences "are disturbing because our children die in our houses and backyards where they are supposed to be safe, as if they're living is shacks. This pains us as women" (Participant 6). To this participant, a house still meant better security and safety, compared to the precarious living conditions in informal settlements.

Women's particular concerns about their children's safety, security and wellbeing in housing are not uncommon. Mwansa, Jankey and Lesetedi (2015:215) point out that "a child's chance of survival increases by $20 \%$ when a mother controls the household budget" and is also physically involved in raising the child. Furthermore, Mwansa et al. (2015) argue that a household budget that is controlled by a woman is more likely to improve the education, nutrition and overall wellbeing of children and family. The author further insists that if housing planning, access and allocation are conducted with gender awareness, then housing and human settlements would be more likely to be safe, inclusive, sustainable and viable. Hence, as argued by Arku (2006:vi) and Carter and Polevychok (2004), housing policy planning should permeate the nation's social policy and development agenda.

The participants also defined housing in terms of its ability to provide safety and security for them as women. For instance, Participant 12, who was also a student, elaborated that "for me, as a young woman and a student, I'm expecting housing to offer me a quiet place, where security is tight. This is because of crime against women. I have to be careful of rape." Participant 13 added that "I'm a woman and I need security, especially because my husband knocks off late and he travels. Rapists and robbers break in people's houses and I'm happy that hasn't happened with us here." From the above responses it is evident that participants define housing based on the security that it provides for them. Participant 14 said that "for me to be safe, as a young single woman, it means that my house needs to be of good quality, strong, lockable and have an alarm plus security at the entrance. That's why I chose this place and been here for six years."

The above fears expressed by the women and their hope that housing would enhance their safety and security is linked to the violent crimes that target women in the country. The literature confirms that gender-based violence is widespread in South Africa (Abrahams et al., 2010; Jewkes et al., 2010; Maphosa \& Rasool, 2017; Woollet \& Thompson, 2016). Statistics South Africa (2018:19) states that "women are more vulnerable to theft of personal property, sexual offence and fraud compared to men ... sexual offences, in particular, stand out with 68.5 per cent of the victims being women."

Based on the findings that housing plays a key role in enhancing the security and the quality of life of women and thus invariably the entire family, it makes sense to have a gender focus influencing policy on housing in order to promote the freedoms and rights of women in South Africa. The motivation for such a stance is also advanced by Gordon, Riger, LeBailly and Heath (1980:144-145), who point out that "women are afraid to walk in their neighbourhoods at night ... and the fear of rape keeps women off the streets at night."

Within this context the author concurs with Depres (1991:107) that "societal processes by which the home is defined, produced and sold must be considered." This particularly refers to including the views of women as to the kinds of housing that they need. Put simply, bottom-up, gender-aware and gender- 
inclusive housing delivery pathways, driven by women, are necessary if human settlements are to meet the safety and security requirements of women, their children and ultimately families (Depres, 1991; Gandhi, 1987; Noyoo \& Sobantu, 2019; Saugeres, 2009; Waetjen \& Vahed, 2012).

\section{Human dignity and self-worth}

The findings of this study indicate that participants saw housing as enhancing their dignity and selfworth as well as that of their families. Thus housing not only yields tangible benefits such as shelter, but also promotes stability, dignity and a sense of pride (Malpass \& Murie, 1999:1; Sobantu et al., 2019). To fully comprehend the nexus between housing (especially as it affects women), human dignity, self-worth and pride, one needs to consider the historical socio-politics of housing at the levels of gender, race and social status. These reflections emerged strongly from the findings, as summed up in the two comments below:

"While we're fully aware that these are subsidised rental houses, we're happy that we never thought we'd access them because these houses were for white people. Right now, we're stable here and the place is clean, the house is good with children having their own bedroom and it makes a parent proud." (Participant 8)

"Life is so difficult as a poor black woman and a single parent in South Africa. Being in a shack in Madelakufa pained me because I saw there was no future for my child that I stayed within one room. But things changed when I got this place, I'm happy because I can invite my friends and relatives." (Participant 5)

The participants' understanding of housing was informed by its function of enhancing stability, dignity and human worth, and social justice, given the poor living conditions most black people experienced during apartheid (Noyoo \& Sobantu, 2019). The relationship between housing and stability is articulated in Kellet and Moore (2003), who note that it is only when occupants have a stable living environment that they can engage in productive, home-making activities and can concentrate on improving their livelihoods. Engaging in home-making activities by women and the entire family enhances a sense of ownership, which has positive spill-over effects in promoting safe and secure neighbourhoods. Both participants in the above responses indicated that their houses were of good quality and children had their own bedrooms.

The above responses also need to be appreciated in the light of the dehumanising conditions in most South African informal settlements, which do not offer privacy for the families. Most of the occupants of subsidised RDP housing have long complained that their units are small and of poor quality (Charlton \& Kihato, 2006; Manomano \& Tanga, 2018; Manomano, Manomano, Tanga \& Tanyi, 2016; Noyoo \& Sobantu, 2019; Qwazi, 2017; Zack \& Charlton, 2003). The participants in this study, however, expressed that they had adequate space for their children and could also invite friends and relatives. In other words, housing not only enhanced the stability of the participants' living environment, giving them an "address [which is an] indicator of social position", but also restored selfesteem and a sense of pride. Hence, the participants conveyed that they understood housing in terms of human dignity, self-worth and pride which they derived from housing. This dovetails with the stance expressed in Sobantu et al. (2019:2) that "housing [delivery is] inseparable and indivisible from the human rights discourse".

Privacy is an important factor in housing and human settlements and is mainly determined by the size of the house. It should be noted that before 1994 the black majority lived in cramped and hazardous conditions that undermined their right to privacy (Hallen, 1976; Matshoba, 1980; Minnaar, 1993; Mosselson, 2015; Noyoo, 2003; Pirie \& Da Silva, 1986).

\section{Convenient location of services and amenities}

The findings indicate that participants felt their houses and settlements were conveniently located, in close proximity to services and amenities. The location of human settlements is key in determining the quality of life of the residents. Participants indicated that they were closer to various transport services such as taxis

\section{Social Work/Maatskaplike Werk 2020:56(1)}


and trains, which they used to reach their sources of livelihood. Those with school-going children remarked that schools were closer to their settlements, while others indicated that their children could easily get to and from school because of the availability of transport. Others compared their locational advantages to the conditions where they had lived previously. Two participants pointed out that

"It's far better here than where I was, we have everything because there's a bus, taxi and train for people to get to work." (Participant 4)

"For me, housing means closeness to transport, clinics, shops and convenience to schools for children. We've lived in worse places before." (Participant 13)

Through policies such as the Native Land Act, the colonial and apartheid administrations arranged housing and settlements into "a space that sorts - a space that classifies in the interests of a class" (Lefebvre \& Nicholson-Smith, 1991:375). It should be emphasised that South Africa's history is tainted by the practices of social and economic discrimination and other forms of exclusion at the level of class, race and gender (Brown \& Neku, 2005; Noyoo, 2003; Noyoo \& Sobantu, 2019). For all the participants, their access to such conveniently located housing meant enormous progress towards gender, racial and social integration. This was articulated by Participant 7:

“... unfortunately my mother passed on without such kind of housing, or even RDP. To her, a house just meant a shack in Diepsloot, where we lived with no electricity, used communal toilets and we could spend days without water. Now, it's different, my perspectives of a house have changed, it means having piped water, electricity and being able to get anywhere you want to because of options of transport. It makes my life easier as a single parent."

Explicit in the above comment is the changed meaning of housing, especially for women who previously had no access to affordable, conveniently located housing, and linked to their socioeconomic rights. Also explicit is the notion of welfare services options. From the findings, it was evident that the participants now had varied options in terms of schools and healthcare facilities. This meant that they could spend less of their income on transport and other services, and hence save more towards education and nutrition. It must be remembered that some of these participants were "women who [were] single parents from impoverished communities [who] faced social and economic exclusion in both the first economy and second economy." Hence there is a need to view housing delivery through a gender lens that prioritises women in accessing affordable, well-located housing. A gender lens in housing delivery expands women's choices in accessing basic needs and fostering humanistic values of redistribution, social justice, human rights and egalitarianism (Noyoo, 2015:170).

\section{AREAS OF CONCERN}

It must be borne in mind that the participants are beneficiaries of social rental housing, which contributes only a tiny proportion of the residential stock in South Africa. This means that the majority of women and families in South Africa live in inadequate housing. While the participants appreciated their access to social rental, which they viewed as "far better than other kinds of places we've stayed in before" (Participant 4), there was a consensus that crime undermined the safety and security, not only theirs, but of all families in their neighbourhoods. For example, Participant 10 stated that "of course we may be relatively safe here, but we're also very unsafe with all others in the community." This reflects the sociological roots of crime in South African communities. It should, however, be pointed out that crime affects women and children more than it does to men. This was confirmed by Gordon, Riger, LeBailly and Heath (1980), who reiterated "women are afraid to walk in their neighbourhoods at night [because of] the fear of rape [that] keeps women off the streets at night" (Gordon et al., 1980, pp. 145-145).

The second area pointed out by the participants as requiring government attention was rising rentals of social rental housing. Participants argued that "most of us are single and have children" (Participant 1), "we occupy very lowly paid jobs and we have to work long hours to pay rents and survive (Participant 7) and "our rentals go up even though my partner is helping me, it's clear that we'll end forced to leave because salaries are still low" (Participant 10). These responses are in line with Charlton's 
(2013) observations that, unlike RDP housing, social rental housing does not cater for the poorest of the poor in South Africa. In view of feminisation of poverty, the rising rentals mean that government and SHIs need to work collaboratively in mitigating this challenge. Apart from the rising rentals, other participants stated that their units and surroundings had been neglected as far as maintenance was concerned. Participants said that "we don't mind paying rent but maintenance pattern has changed" (Participant 3), while another noted that "it's not good that broken geysers remain unattended, and drains leak for two or so days, but we pay rent." This third challenge also demands collaborative work by the government, SHIs and participants. For examples, untrimmed lawns and unmaintained infrastructure can becomes a breeding ground for bacteria and pests, which pose a health risk for the occupants (Rivault, Cloarec \& Le Guyader, 1993).

\section{RELEVANCE OF GENDER AND HOUSING TO SOCIAL WORK}

Challenges around gender and lack of housing, especially for women, are social work concerns. This paper has established the positive interaction between these aspects and family wellbeing. Despite the centrality of housing for women, they continue to experience various barriers to housing access, such as poverty and patriarchy. Housing is a basic human right and therefore if women, who are classified as a vulnerable population, are discriminated against in accessing housing, their exclusion becomes a social work issue. There is a correlation between the lack of housing for women and their vulnerability to many forms of abuse (Paglione, 2006). This paper has argued that, for social work to be more relevant in fighting gender-based and domestic violence, the profession urgently needs to influence policy towards promoting gender-aware housing delivery. Through advocacy, the profession needs to direct policy towards promoting the rights of women and gender equality. This is part of policy practice, which involves the application of social work skills to propose, change and create inclusive social and economic policies (Director \& Clark, 2011). As argued by Carter and Polevychok (2004:vi), housing policy planning should take "place at the table with education and health care when spending priorities are discussed", because of the potential benefits of fostering gender equality, curbing gender-based violence, promoting children's education, and ensuring social and economic integration.

Director and Clark (2011) stress that the main goal of social work is to "help powerless groups such as women, children, poor people, people of colour, gay men and lesbians and people with disabilities" (Jansen, 2005 in Director \& Clark, 2011:8). Furthermore, Noyoo (2010:23) reiterates that "policy measures [should] protect the welfare of the vulnerable in society" and promote social justice and the human rights of vulnerable populations. The National Association of Social Work (NASW) Code of Ethics underscores the view that social work as a profession is committed to helping vulnerable persons, including women, to meet their basic human needs, such as housing (NASW, 2008). By examining this issue through a gender lens, the paper has shown the various ways in which women are discriminated against in accessing housing and it thus helps to positively influence the interactions between social workers, homeless women and housing service providers. These social workers will be more informed when advocating for the homeless women in an endeavour to promote gender equality and the human rights of women.

\section{CONCLUSION}

Finally, the author reiterates that housing plays a significant role in the social and economic wellbeing of families and communities. However, although the paper reflects the positive sentiments of a few women who have access to social rental housing, the provision of low-income housing remains an ongoing challenge in the country. In addition, a large proportion of women continue to reside in informal settlements, being discriminated against in the context of the feminisation of poverty and patriarchy. The situation is worse for women, because of their low income and other structural impediments such as racism and patriarchy. This paper has reflected on how adequate housing is important for women. Overall, it is argued that housing and social policy need to be planned in a more purposeful way that takes into account the numerous benefits that would stem from a gender-aware approach to policy making. 


\section{REFERENCES}

ABRAHAMS, N., JEWKES, R., LAUBSCHER, R. \& HOFFMAN, M. 2006. Intimate partner violence: prevalence and risk factors for men in Cape Town, South Africa. Violence and Victims, 21(2):247-264.

ABRAHAMS, N., JEWKES, R. \& MATHEWS, S. 2010. Guns and gender-based violence in South Africa. South African Medical Journal, 100(9):586-588.

ANDERSON, I. 2010. Services for homeless people in Europe: Supporting pathways out of homelessness. In O'Sullivan, E Busch-Geertsema, V, Quilgars, D \& Pleace, N. (eds), Homelessness research in Europe (pp. 41-63). Brussels: European Federation of National Organisations working with the Homeless.

ANNEY, V.N. 2014. Ensuring the quality of the findings of qualitative research: looking at trustworthiness criteria. Journal of Emerging Educational Research and Policy Studies, 5(2):272281.

ARKU, G. 2006. The housing and economic development debate revisited: Economic significance of housing in developing countries. Journal of Housing and the Built Environment, 21(4): 377-395.

BOURDIEU, P. 1990. The logic of practice. Cambridge: Polity.

BRAUN, V. \& CLARKE, V. 2006. Using thematic analysis in psychology. Qualitative

Research in Psychology, 3:77-101.

BROWN, M. \& NEKU, R.J. 2005. A historical review of the South African social welfare system and social work practitioners' views on its current status. International Social Work, 48(3): 301-312.

CARTER, T. \& POLEVYCHOK, C. 2004. Housing is good social policy. Ottawa: Canadian Policy Research Networks.

CHARLTON, S. 2013. State ambitions and peoples' practices: an exploration of RDP housing in Johannesburg, University of Sheffield. Sheffield, United Kingdom: (Unpublished Doctoral thesis)

CHARLTON, S. \& KIHATO, C. 2006. Reaching the poor? an analysis of the influences of the evolution of South Africa's housing programme. In Pillay, U. Tomlison, R. \& Du Toit, J. (eds), Democracy and delivery: urban policy in South Africa. Cape Town: Human Sciences Research Council (HSRC): 224-265.

CSIKSZENTMIHALYI, M. \& HALTON, E. 1981. The meaning of things: Domestic symbols and the self. Cambridge: Cambridge University Press.

DESPRES, C. 1991. The meaning and use of home. Journal of Architectural and Planning Research, 8(2):96-115.

DIETRICH, G. 1987. Women's struggles for housing. Economic and Political Weekly, 22(42/43):1793-1794.

DIRECTOR, N.E. \& CLARK, E.J. 2011. Defining Policy Practice in Social Work. In: L.K. Cummins, K.V. Byers \& L.E. Pedrick, (eds), Policy practice for social workers: New strategies for a new era. Boston, MA: Allyn and Bacon: 1-25.

FISH, M. 2003. Social housing. In Khan, F. \& Thring, P. (eds), Housing policy and practice in postapartheid South Africa. Cape Town: Heinemann Publishers: 404-421.

FREITAS, F.A. \& LEONARD, L.J. 2011. Maslow's hierarchy of needs and student academic success. Teaching and Learning in Nursing, 6(1):9-13.

GANDHI, N. 1987. Gender and housing. Economic and Political Weekly, 22(47):1994-1997. 
GILL, P., STEWART, K., TREASURE, E. \& CHADWICK, B. 2008. Methods of data collection in qualitative research: Interviews and focus groups. British Dental Journal, 204(6):291-295.

GORDON, M.T., RIGER, S., LEBAILLY, R.K. \& HEATH, L. 1980. Crime, women, and the quality of urban life. Journal of Women in Culture \& Society, 5:160-168.

GQOLA, P.D. 2007. How the 'cult of femininity' and violent masculinities support endemic gender based violence in contemporary South Africa. African Identities, 5(1):111-124.

GREEF, M. 2013. Information collection: Interviewing. In De Vos, A. S., Strydom, H,

FOUCHE, C.B. \& DELPORT, C.S.L. (eds), Research at grassroots: For the social sciences and human service professions $4^{\text {th }}$ ed, Cape Town: Van Schaik: 341-375.

HALLEN, H. 1976. The quality of life and urban development. Optima, 26:200-216.

HOHMANN, J. 2013. The right to housing law, concepts, possibilities. Oxford: Hart Publishing.

HOLMAN, M.C. 1968. The urban crisis: challenge and response. Transactions of Society of Actuaries, 20(58):316-323.

HUCHZERMEYER, M. 2001. Housing for the poor? Negotiated housing policy in South Africa. Habitat International, 25:303-331.

JACKSON, C. \& PEARSON, R. 1998. Feminist visions of development: gender analysis and policy. London: Routledge.

JEWKES, R.K., DUNKLE, K., NDUNA, M. \& SHAI, N. 2010. Intimate partner violence, relationship power inequity, and incidence of HIV infection in young women in South Africa: a cohort study. The Lancet, 376(9734):41-48.

JONES, A. 2014. Making do with less: the housing experiences of single mothers in Kelowna's rental housing market The University of British Columbia, Okanagan, British Columbia: Master's Thesis

JONES, A. \& TEIXEIRA, C. 2015. Housing experiences of single mothers in Kelowna's rental housing market. Canadian Journal of Urban Research, 24(2):117-137.

KELLET, P. \& MOORE, J. 2003. Routes to home, homelessness and home-making in contrasting societies. Habitat International, 27: 123-141.

KHAN, F. 2003. Continuities, ambiguities and contradictions: the past, present and (possible) future of housing policy and practice in South Africa. In Khan, F. \& Thring, P. (eds), Housing policy and practice in post-apartheid South Africa (pp. 1-84). Cape Town: Heinemann Publishers.

LANUS, R.M. 2009. Do poor housing conditions affect educational attainment? An analysis of the impact of poor housing conditions on educational achievement, a study based in Buenos Aires, Argentina. Georgetown University, Washington, DC, United States of America: Master's Thesis

LARSON, A. 2001. Gender perspectives in housing and planning. Building Issues, 11(1): 32-47.

LEFEBVRE, H. \& NICHOLSON-SMITH, D. 1991. The production of space (Vol. 142). Oxford: Blackwell.

MALPASS, P. 2001. Housing associations and housing policy: A historical perspective ( $2^{\text {nd }}$ ed). London: Macmillan Press.

MALPASS, P. \& MURIE, A. (eds). 1999. Introduction: analysing housing policy. In Malpass, P. \& Murie, A. (eds), Housing policy and practice. London: Palgrave Macmillan: 1-19

MANOMANO, T. \& TANGA, P. 2018. Housing needs: the quality and quantity of housing provided by the government for the poor in the Eastern Cape Province in South Africa. Social Work/Maatskaplike Werk, 54(1):19-36. 
MANOMANO, T., TANGA, P.T. \& TANYI, P. 2016. Housing problems and programmes in South Africa: A literature review. Journal of Sociology and Social Anthropology, 7(2):111-117.

MAPHOSA, N. \& RASOOL, S. 2017. The effectiveness of perpetrator programmes in promoting positive gender relations and preventing domestic violence: A case study of NICRO'S PIPV programme. Gender and Behaviour, 15(2):9100-9107.

MATLALA, A. 2019. Giyani water project payment spat leads to boy drowning. [Online] Available: https://citizen.co.za/news/south africa/government/2062580/giyani-waterproject-payment spat-leads-to-boy-drowning/. [Accessed 04/01/2019].

MATSHOBA, M. 1980. To kill a man's pride. In M. Mutloatse (ed), Forced landing. Johannesburg: Ravan Press: 103-127.

MINNAAR, A.D.V. (ed). 1993. Communities in isolation: Perspectives on hostels in South Africa. Pretoria: Human Sciences Research Council (HSRC).

MORSE, J.M. 1991. Strategies for sampling. In: J. M. Morse (ed), Qualitative nursing research: A contemporary dialogue. Thousand Oaks, CA: Sage Publications: 127-145.

MOSSELSON, A, 2015. Vernacular regeneration low-income housing, private security and urban transformation in inner city Johannesburg. University College London, United Kingdom: Doctoral thesis

MULROY, A. 1988. Women as single parents: Confronting institutional barriers in the courts, the workplace, and the housing market. London: Auburn House.

MWANSA, L.J., JANKEY, O. \& LESETEDI, G. 2015. Situating the family in social Development in Africa. In: Calvelo, Lutz, R \& Ross, R. (eds), Development and social work: social work of the south. Oldenburg: Paulo Freire Verlag: 201-222.

NATIONAL ASSOCIATION OF SOCIAL WORKERS (NASW). 2008. NASW Code of Ethics. Retrieved from [Online] Available: http://www.socialworkers.org/pubs/code/code.asp [Accessed 23/04/2019].

NISHIMWE-NIYIMBANIRA, R. 2013. The relationship between gender and poverty in a South African township. North-West University (Vaal Triangle Campus), Vanderbijlpark, South Africa: Master's Thesis

NOYOO, N. 2003. Social welfare policy, social work practice and professional education in a transforming society: South Africa. University of the Witwatersrand, Johannesburg, South Africa: Doctoral thesis

NOYOO, N. 2015. Social development in Southern Africa. In Calvelo, L. Lutz, R. \& Ross, R. (eds).

Development and social work: social work of the South Oldenburg: Paulo Freire Verlag: 167-185.

NOYOO, N. 2010. Social policy and human development in Zambia. London: Adonis \& Abbey Publishers Ltd.

NOYOO, N. \& SOBANTU. M. 2019. Deconstructing and decolonising spatiality: voluntary and affordable housing for a transforming Johannesburg. In: MYAMBO, M. T. (ed), Reversing urban spatiality. London: Routledge: $35-42$.

OLUFEMI, O. \& REEVES, D. 2004. Lifeworld strategies of women who find themselves homeless in South Africa. Planning Theory and Practice, 5(1): 69-91.

ÖZLER, B. 2007. Not separate, not equal: Poverty and inequality in post-apartheid South Africa. Economic Development and Cultural Change, 55(3): 487-529.

PAGLIONE, G. 2006. Domestic violence and housing rights: A reinterpretation of the right to housing. Human Rights Quarterly, 28(1): 120-147. 
PIRIE, G.H. \& DA SILVA, M.M. 1986. Hostels for African migrants in greater Johannesburg. GeoJournal, 12(2):173-182.

PILLAY, J. 2017. The relationship between housing and children's literacy achievement: Implications for supporting vulnerable children. Southern African Journal of Education, 37(2):1-10.

PITHOUSE, R. 2009. A progressive policy without progressive politics: Lessons from the failure to implement' Breaking New Ground'. Town and Regional Planning, 54:1-14.

QWAZI, C. 2017. No room to poke in tiny RDP houses [Online] Available:

https://www.dailysun.co.za/News/National/no-room-to poke-in-tiny-rdp houses-20170912 [Accessed $15 / 11 / 2018]$.

RAKOFF, R.M. 1977. Ideology in everyday life: the meaning of the house. Politics and Society, 7(1):85-104.

RANIGA, T. 2018. Poverty alleviation, social protection policy and sustainability of economic development cooperatives: voices of women residing in Bhambayi, Kwazulu-Natal, South Africa. Social Work/Maatskaplike Werk, 54(4):395-406.

RANIGA, T. \& NGCOBO, N. 2014. Economic experiences of single mothers in Bhambayi, KwazuluNatal, South Africa. Social Work/Maatskaplike, 50(4):516-528.

REPUBLIC OF SOUTH AFRICA (RSA). 2005. Social Housing Policy. Pretoria: Government Printer. REPUBLIC OF SOUTH AFRICA (RSA). 2008. Social Housing Act. Pretoria: Government Printer.

SAUGERES, L. 2009. We do get stereotyped: Gender, housing, work and social disadvantage. Housing, Theory and Society, 26(3):193-209.

SEBBA, R. \& CHURCHMAN, A. 1986. The uniqueness of the home. Architecture and Behaviour, 3(1):7-24.

SHANGE, N. 2018. Deadly wall collapse: 'it sounded like a big car crash'. [Online] Available: https://www.timeslive.co.za/news/south-africa/2018-04 09-deadly-wall-collapse-it-sounded-like-a-bigcar-crash/ [Accessed 24/11/2018].

SHENTON, A.K. 2004. Strategies for ensuring trustworthiness in qualitative research projects. Education for Information, 22(2): 63-75.

SMYTH, I. 2007. Taking of gender: Words and meanings in development organisations. Development and Practice, 17(4): 582-588.

SOBANTU, M. 2014. What has enabled WASSUP, a water and sanitation based communitybased organisation (CBO) to emerge and endure over a period of time. Johannesburg, University of the Witwatersrand, South Africa: Master's Thesis

SOBANTU, M. 2019. A model for enhancing voluntary housing within a social development approach in South Africa Johannesburg, University of Johannesburg, South Africa: Doctoral Thesis

SOBANTU, M. \& WARRIA, A. 2013. Lifting the veil of silence: exploring academic experiences of male refugee learners at a high school in Johannesburg, South Africa. Social Work/Maatskaplike Werk, 49(4):570-584.

SOBANTU, M., ZULU, N. \& MAPHOSA, N. 2019. Housing as a basic human right: A reflection on South Africa. Southern African Journal of Social Work and Social Development, 31(1): 1-18.

SOCIAL HOUSING REGULATORY AUTHORITY (SHRA). 2018. Regulate. [Online] Available: http://www.shra.org.za/search?searchword=letting\&searchphrase=all [Accessed 24/11/2018].

STATISTICS SOUTH AFRICA (STATS SA). 2018. Quarterly labour force survey (QLFS) Q1: 2018. 

$15 / 11 / 2018]$.

[Accessed

TILLEY, E., BIERI, S. \& KOHLER, P. 2013. Sanitation in developing countries: A review through a gender lens. Journal of Water, Sanitation and Hygiene for Development, 3(3): 298-314.

TODES, A., MALAZA, N. \& WILLIAMSON, A. 2009. Gender in Planning and Urban Development (Commonwealth Secretariat Discussion Paper, Number 7). [Online] Available: http:// wiredspace.wits.ac.za/bitstream/handle/10539/16842/Malaza\%2C\%20Nqobile\%20et\%20al.\%20Gende r\%20in\%20Planning\%20and\%20Urban\%20Development.pdf?sequence=1\&isAllowed=y [Accessed $13 / 08 / 2018]$.

WAETJEN, T. \& VAHED, G. 2012. Gender, citizenship and power: the Westcliff Flats Residents Association. The Oriental Anthropologist, 12(2): 249-268.

WICKS, J. 2018. Two girls killed in Durban wall collapse. Sunday Times. [Online] Available: https://www.timeslive.co.za/news/south-africa/2018-05-21-two-girls-killed-in-durban wall-collapse/. [Accessed 30/05/2018].

WOOLLET, N. \& THOMSON, K. 2016. Understanding the intergenerational transmission of violence. South African Medical Journal, 106:1068-1070.

ZACK, T. \& CHARLTON, S. 2003. Somewhat better life: Beneficiaries' perceptions of subsidised housing. Johannesburg: Housing Finance Resource Programme.

ZAVEI, S.J. A.P. \& JUSAN, M.M. 2012. Exploring housing attributes selection based on Maslow's hierarchy of needs. Procedia-Social and Behavioral Sciences, 42:311-319. 